representation of it with Balmain's Juminous paint. When dry the drawing may be hung up in the lecture-hall and covered with black tissue-paper until required. At the appointed time the lights are lowered, the tissue-paper withdrawn, and magnesium wire burnt in front of the painting. I had last week the pleasure of showing this to an audience of 500 persons, and from the expressions of curiosity and approval found it to be a very taking experiment.

Sowerby Bridge, March ro

\section{Squirrels Crossing Water}

HAVING read in NATURE the two interesting communications on Squirre!s Crossing Water, I was so free as to cite them in my paper Lumir, requesting the readers to let me know whether any of them had seen instances of squirrels taking to water bere in Bohemia. Upon this I received from my friend Prof. A Tiráseh of Litomysl the following :-

"You seem to doubt of squirrels taking to water, and I hasten to give you notice of what I myself witnessed when a boy. With the help of other young fellows like myself I succeeded in driving a squirrel down from an old ash-tree that stood in our garden, not far from the River Medhuje (Metan). The squirrel must have come from the other side of the water, where there was a wood, and must have crossed the river. Of this however I cannot be sure, but when driven down from the tree, and seeing its way to landward cut off, the squirrel turned to the river, and sprang in, I following it. Now it swam very cleverly, but was overtaken by me in the middle of the water, and brought back in triumph, of course with my hands all bleeding from its sharp teeth, which the animal used cleverly too."

Prague, March 13

T. V. SLÁDEK

\section{Tacitus on the Aurora}

THERE is a passage in the "Germania" of Tacitus (chapter xlv.) which I do not think can have ever been examined by the historians of natural science, or it would have created a considerable stir amongst them. Side by side with a plain account - probably the earliest written one-of an arctic twilight, there lurks in it a description of the aurora borealis, which moreover lends countenance to the still prevailing notion that the northern lights are accompanied by sound.

Speaking of the Suiones, a tribe on the northern borders of Germany, the great writer says :- " Beyond them is another sea, calm even to stagnation, by which the circle of the earth is believed to be surrounded and confined; because the last gleam of the setting sun lingers till he rises again, and so brightly that it dims the stars. It is believed too that a sound is heard, that the forms of gods and rays from a head are seen (persuasio adjicit sonum audiri insuper formas deorum et radios capitis adspici). $\mathrm{Up}$ to that point [however]-and the report [I have given] is true-everything is natural."

As to the question of sounds being heard, the din of carts and factories in our city, and the roar of trains in our suburbs make an observation here for determining it impossible; while the rarity of the phenomenon in England generally keeps spectators from being on the watch. But I have heard an intelligent old man who has often gazed on the bright streamers during the clear still nights of Aberdeenshire declare that he has plainly observed sharp switching sounds to proceed from them. It seems to me probable, since electricity can change into sound and takes part in producing the aurora, that the spectacle is attended by audible vibrations.

Chislehurst, Kent

ON THE PRACTICABILITY OF LIVING AT GREAT ELEVATIONS ABOVE THE LEVEL OF THE $S E A^{1}$

" $U \mathrm{P}$ to this time most of the loftiest portions of the earth are totally unexplored, and this arises principally from the fact that the mountaineer, in addition to experiencing all of the troubles which occur to other travellers, has to deal with some which are peculiar to his work. I do not now refer to the 'distressing hæmor-

$x$ Extracts made, by permission of the author, from a lecture delivered by Edward Whymper to the Society of Arts in the Theatre at South Kensington, March 9, 1881- "On Chimborazo and Cotopaxi." rhages,' 'alarming vomitings,' and ' painful excoriations which are said to afflict him. Hæmorrhage and excoriation are rather large words, and they are apt to be alarming if they are not translated. But they do not seem so very formidable if they are rendered 'bleeding at the nose' and 'loss of skin through sunburn'; and it may perhaps tend still further to allay alarm if I say that I have never known bleeding at the nose to occur upon a mountain except to those who were subject to the complaint ; while with regard to vomitings, although such unpleasant occurrences do happen, they have only been known when persons have taken that which has disagreed with them.

"There is, however, behind these, another trouble, which cannot be dismissed so lightly. All travellers, without exception, who have ever attained to great altitudes, have spoken of having been affected by a mysterious complaint, and this complaint is known to affect native races living in high mountain regions, as well as casual travellers. With us it is usually called mountain sickness. There are many native names for it, and numerous conjectures have been put forward as to its cause. Very commonly it is supposed to be the work of evil spirits, or mysterious 'local influences'; but there is no doubt that it is simply an effect which is the result of the diminution in the atmospheric pressure which is experienced as one goes upward. The reduction which takes place at great heights is quite sufficient to account for disturbance of the human system. At 20,000 feet pressure is less than half the amount that it is at the level of the sea; that is to say, whereas at the level of the sea atmospheric pressure is generally capable of sustaining a column of mercury of thirty inches, at 20,000 feet it will not sustain a column of fifteen inches.

"From air-pump experiments, and from purely pbilosophical considerations, it is obvious that the human system must be liable to derangement if subjected to sudden diminution of the atmospheric pressure to which it has been accustomed. These disturbances have of ten been so severe as to render mountain travellers incapable, and their lives well-nigh unendurable; and it is scarcely to be wondered at that they have endeavoured to escape from the infliction by descending into lower regions. I do not know a single instance of a traveller who, having been attacked in this way, has deliberately, so to speak, sat it out, and had a pitched battle with the enemy. Nor am I aware that any one has even suggested the bare possibility of coming out victorious from such an encounter. Yet, upon doing so, depended the chance of pushing explorations into the bighest regions of the earth; and I long felt a keen desire to know whether my own organisation, at least, could not accommodate itself to the altered conditions. From considerations which would occupy too long to enter into now, I gradually acquired the conviction that patience and perseverance were the principal requisites for success ; and the journey of which $\mathrm{I}$ am now going to speak was undertaken with the view of bringing this matter, amongst other things, to a definite issue. In the course of it we camped out at very great heights. Twenty-one nights were, spent above 14,000 feet above the level of the sea; eight more above 15,000 feet; thirteen more above I 6,000 feet ; six more above I7,000 feet; and one more at 19,450 feet. I shall not now anticipate what you will presently hear, and I have made these preliminary observations to render less frequent the interruption of the narrative, and for the purpose of explaining allusions in it which might otherwise perhaps have been only half-understood."

After describing the route taken to Chimborazo, Mr. Whymper proceeded to mention the first journey he made to that mountain; and said that whilst returning from it to the town of Guaranda (8870 feet), whilst still about 13,000 feet above the sea, he was overcome by dizziness, feverishness, and intense headache, and had to be supported by two of his people for the greater part of the 
way. "Imagining that I was attacked by fever, I took thirty grains of sulphate of quinine in the course of the night, and was covered up with a mountain of blankets; but next morning there was nothing the matter, and as the symptoms were precisely those which occurred at a later period, when we were evidently affected by low atmospheric pressure, I ultimately concluded that it was through this that the indisposition was caused.

"At this point allow me to say a few words further with regard to the troubles which occur to persons who get to great altitudes. Although the heights of the Andes which we were about to visit had not been well determined, there was reason to believe that several of them approached, if they did not exceed, 20,000 feet. At the time of our departure there were only three tolerably well-authenticated instances of persons having reached that height on land, and I could learn nothing whatever which was of the least service respecting the experiences of those who were engaged in those expeditions. But from others, who had reached altitudes of from 17,000 to 18,000 feet, I heard a confirmation of my supposition that, at such great elevations, I ought not to expect a continuance of the immunity from mountain sickness which I had hitherto enjoyed.

"I made up my mind, therefore, before we left, that, sooner or later, we should suffer like the rest of the world; but, being of opinion, as I have already said, that patience would overcome mountain sickness, it was my intention, on all our expeditions, first to establish camps as high as we could force the natives and mules. As it would be impossible to retain the natives at those positions, it became necessary to provide ourselves with food sufficient for weeks, or even for months, so that, in the event of our failing in our enterprises, either from badness of weather, mountain sickness, or other causes, we should not have the mortification of being obliged to abandon our positions simply from want of sustenance."

Mr. Whymper then described the establishment of his second camp on Chimborazo at the height of I6,500 feet above the level of the sea, and said, "Although we had succeeded in establishing our camp on the selected spot, it had only been done by the greatest exertions on the part of my people and their beasts. The mules were forced up to the very last yard that they could go, and staggering under their burdens (which were scarcely more than half the weight they were accustomed to carry), stopped repeatedly, and by their trembling, falling on their knees, and general behaviour, showed that they had been driven to the verge of exhaustion. When we arrived at the second camp, we ourselves were in good condition; which was to be expected, as we had ridden up the entire distance from Guaranda; but within an hour I found myself lying on my back, along with both of the Carrels, placed hors-decombat, and incapable of making the least exertion. We knew that our enemy was upon us at last, and that we were experiencing our first attack of mountain sickness.

"We were feverish, had intense headaches, and were unable to satisfy our desire for air, except by breathing with open mouths. This naturally parched the throat, and produced a craving for drink, which we were unable to satisfy, partly from the difficulty of obtaining it, and partly from the difficulty of swallowing it. For, when we got enough, we were unable to drink, we could only sip; and not to save our lives could we have taken a quarter of a pint at a draught. Before one-tenth part of it was down, we were obliged to stop for breath, and gasp again, until our throats were as dry as ever. Besides having our normal rate of breathing largely accelerated, we found it impossible to get along, without every now and then giving a spasmodic gulp, just like fishes when they are taken out of water. Of course there was no desire to eat; but we wished to smoke; and found that our pipes almost refused to burn, for they, like ourselves, wanted more oxygen.

This condition of affairs lasted all night and all the next day, and I then managed to pluck up spirit enough to get out the chlorate of potash, which, by the advice of Dr. Marcet, I had brought in case of need. Chlorate of potash was, I believe, first used in mountain travel by Dr. Henderson, in the Karakorum range, and it was subsequently employed on Sir Douglas Forsyth's Mission to Yarkand in $1873-4$. The surgeon to the expedition states that he distributed little bottles of it amongst the members of the embassy, and says that, from his own experience, he can testify to its value in mitigating the distressing symptoms produced by a continued deprivation of the natural quantity of oxygen in the atmosphere. Before my departure, Dr. Marcet urged me to experiment, with the view of confirming these experiences. Ten grains to a wine-glass of water was the dose recommended, to be repeated every two or three hours if necessary. I say distinctly that I thought it was of use, though it must be admitted it was not easy to determine, as one might have recovered just as well without taking any at all. Anyhow, after taking it the intensity of the symptoms diminished; there were fewer gaspings, and in a degree a feeling of relief. I am so far in favour of its use, that I shall always carry it on future expeditions. Louis Carrel also submitted himself to experiment, and seemed to derive benefit, but Jean Antoine, the elder of the two, sturdily refused to take any doctor's stuff, which he regards as an insult to intelligence.

"It seems curious to relate that Mr. Perring (interpreter) did not appear to suffer at all. Except for him we should have fared somewhat badly. He kept the fire going -no easy task, for the fire appeared to suffer from want of oxygen just like ourselves, and it required such incessant blowing that I shall consider for the future a pair of bellows an indispensable part of a mountaineer's equipment. Mr. Perring behaved on Chimborazo in an exemplary manner. He melted snow, and brought us drink, and attended to our wants in general. It goes, therefore, somewhat against the grain to say that he had been for a number of years in Ecuador much addicted to pursuits which play havoc with the human frame. $\mathrm{He}$ was so far debilitated that he could not walk a quarter of a mile on a flat road without desiring to sit down, or 100 yards on a mountain side without being obliged to rest. Had I been aware of his previous history, he certainly would not have accompained us.

"You will naturally inquire-How can you account for this man, of shattered constitution (who also was no mountaineer) being unaffected, when the three others, who where all more or less accustomed to high ascents, were for a time, completely incapable? The explanation appears to be this. Perring had been for a long time residing in the interior, at heights of from 9000 to 10,000 feet, and had several times passed backwards and forwards over the Arenal, a height of over I 4,000 feet. The mean elevation at which he had resided during the previous ten years was, in all probability, much higher than the mean elevation at which we others had lived; and it would probably have been found, had he been subjected to examination, that his manner of respiration, and even his organs of respiration, had become better adapted to a pressure of $16 \frac{1}{2}$ inches, which was the height of the mercurial column at our second camp." *

Mr. Whymper and his Italian mountaineers remained in the same condition for several days. At length the Carrels, becoming better, were eager to be off exploring, and they were sent upwards to find a higher camping place. "They returned soon after dusk, both extremely exhausted. They could scarcely keep on their legs, and threw themselves down and went to sleep, without eating or drinking. Their condition, and the report which I heard next day, rendered it certain that our second camp, as a 
starting-point, was not placed high enough. It appeared that the Carrels, neglecting their instructions, had made a push towards the summit, but had reached a height of only about 19,000 feet. As they were quite unencumbered, carrying no instruments, and only enough food for their own use, and had no traveller to look after, and yet came back quite exhausted, it was obvious that we should have to get still higher up before we could make a serious effort to reach the summit. So, as soon as he was well enough, I sent Louis with Perring down to the first camp to fetch up a tent, which had been left there, and when this arrived we were in a position to go forward again.

"On the following morning I went myself up the ridge to look for a higher camping place, and found one on the eastern side on some broken rocks, at a height of 17,400 feet. By this time I was in rather better condition than the Carrels. Feverishness had disappeared, and my blood had resumed its normal temperature. The yaspings had entirely ceased, and headache had gone. You will perhaps inquire how I knew that I was feverish ; for in regard to this matter one is often mistaken, and fever is supposed when it does not exist. By the advice of the distinguished physician whose name has been already mentioned, Dr. Marcet, I had provided myself with a registering clinical thermometer for the purpose of taking blood temperature at great elevations. This was duly done, and in respect to this matter nothing more need be said than that at our greatest heights the temperature of the blood was (just as it is at the level of the sea) higher during periods of warmth, and lower when it was unusually cold ; but stood at its normal height, when the thermometer was at $60^{\circ}$ or thereabouts, and did not appear to be affected by low atmospheric pressure at all. In recommending me to take this little instrument (which I have in my hand), Dr. Marcet rendered me a great service; and amongst all the devices and instruments which have been pressed upon the attention of travellers in general, of late years, I know nothing equal to it in importance. By constant observation, I was able to detect the earliest advances of fever; and by taking proper steps in time, was able to get through the entire journey without having an attack of fever worth mentioning. Its expense is trifling, and it can easily be carried in the waistcoat pocket. When we were first laid on our backs by mountain sickness, it showed that my blood temperature mounted to $100^{\circ} 4$, but by the end of the year it had fallen to its usual height, viz., $98^{\circ}$. Still, although the more disagreeable symptoms had gone, we found ourselves remaining comparatively lifeless and feeble, with a strong disposition to sit down when we ought to have been moving." * *

$\mathrm{Mr}$. Whymper then described his first ascent of Chimborazo, and concluded his account of this mountain by saying, "My residence on Chimborazo thus extended over seventeen days. One night was passed at a height of 14,400 feet, ten at a height of 16,500 feet, and six at 17,300 feet. During this time, besides ascending to the summit, I also went three times as high as 18,500 feet. When we quitted the mountain, all trace of mountain sickness had disappeared, nor did it touch us again until we arrived at the summit of Cotopaxi.

'The height of Cotopaxi is 19,600 feet. Our camp was placed about I 30 feet below the loftiest point, and it was the most elevated position at which any of us had ever slept. We remained there twenty-six consecutive hours, feeling slightly at first the effects of low pressure, having the same symptoms as we had noticed on Chimborazo; and we used chlorate of potash again with good effect. All signs of mountain sickness had passed away before we commenced the descent, and they did not recur again during the journey. *

"This, ladies and gentlemen, nearly brings my remarks to a close, and, in conclusion, permit me to say a word more in respect to mountain exploration in general. Amongst certain persons it is still fashionable to affect a description of scorn, bordering on contempt, for anything in connection with mountains and mountain work. None of us feel, perhaps, very deeply the criticism of those who are evidently ignorant of the subjects on which they talk and, in this matter, speaking for myself, I rather look forward to the time, which will surely come, when the study of mountains, the ascent of mountains, and even prolonged residence on mountains, will be found essential for the prosecution of a score of sciences. Before this could be carried out, it was necessary to learn whether life could be made endurable at great heights. We were always haunted by the fear of an invisible enemy who might strike us down at any moment. What we wanted to know was, not whether life could exist at a height of 20,000 feet (that was settled seventy-five years ago, by Lussac), but whether man could become so far babituated to the low pressure which is experienced at that height, as to be able to live without inconvenience, and to do useful work. I went to the Andes in search of an answer to these questions, you have heard the story, and can form an opinion whether it affords encouragement for the prosecution of exploration in other quarters."

\section{ON SOME POINTS RELATING TO THE DYNAMICS OF "RADIANT MATTER"}

$\triangle \mathrm{S}$ the important researches of $\mathrm{Mr}$. Crookes may be said to have made the evidence of the molecular state of matter (grounded on indirect reasoning) almost ocularly visible--the mechanics of gaseous matter therefore acquires a fresh interest. As some years back the present writer devoted much thought to the clear realisation of the nature of the motions of the molecules of gases in connection with a proposed explanation of the mode of propagation of sound on the basis of the kinetic theory (published in the Philosophical Magazine for June, I877), it then appeared to him that the systematic regularity of the motions of the molecules of gases was not in practice so generally appreciated as it might be; although of course the mathematical basis of the subject was well established. It has been not unusual to speak of the extreme "irregularity" of the normal motions of gaseous molecules--which is undoubtedly true of any molecule taken individually. The comparison of the molecules of a gas to a "swarm of bres" (sometimes adopted), though no doubt highly convenient and useful to aid the conceptions in some respects, has probably gone to support (rather than not) the idea of a kind of confusion in the motions of the constituent molecules of gases; whereby the systematic regularity (or symmetry of the motion) tends to be left out of view. This will perhaps appear more evident if I state the following proposition in regard to a gas, which is only a direct corollary from the established mathematical principles-true in every state of the gas, but emphasised by rarefaction.

The normal motion of the molecules of a gas takes place in such a way, that every point in the gas is a "radiant point," such that matter passes to and from that point (to a certain distance) in the direction of rays: i.e. as if a luminous point were situated at the point in question. Or more generally put: If finely subdivided matter be in motion in space according to its own dynamics, every point of space becomes a radiant point ; the extent of the radiation of matter depending on its fineness (other things being equal).

It is, I believe, the losing sight of the systematic regularity (or symmetry) of the motion of the molecules of a gas in its normal state, which (as it would seem, at ltast) has caused the connection of gaseous motion with the conditions for gravity to be overlooked-or the fact to escape realisation that on rarefying the gas, this symmetry of motion (existing in the normal state of the gas) gradu- 